Çukurova Üniversitesi Mühendislik Mimarlık Fakültesi Dergisi, 31(2), ss. 269-277, Aralık 2016

\title{
Dolgu Duvarlı Yapılarda Yumuşak Kat ve Zayıf Kat Düzensizliklerinin İncelenmesi
}

\author{
Duygu ERTÜRKMEN" ${ }^{* 1}$, İsmail Hakkı ÇAĞATAY ${ }^{1}$ \\ ${ }^{1}$ Çukurova Üniversitesi, Mühendislik Mimarlık Fakültesi, İnşaat Mühendisliği Bölümü, Adana
}

Geliş tarihi: 07.06.2016 Kabul tarihi: 23.11.2016

$\ddot{\mathbf{O} z}$

Bu çalı̧̧mada, 2007 Deprem Yönetmeliği'nde tanımlanan yapı düzensizliklerinden olan, yumuşak kat ve zayıf kat düzensizlikleri incelenmiştir. Bu amaçla, farklı geometriye sahip 10 katlı, 5 farklı dolgu duvarlı yapı, her iki deprem yönü doğrultusunda Eşdeğer Deprem Yükü Yöntemi kullanılarak analiz edilmiştir. Dolgu duvarlar, eşdeğer basınç çubuğu modeli ile modellenmiş ve yapılan analizlerde SAP2000 programı kullanılmıştır. Sirasıyla C, D, E, F ve G olarak isimlendirilen yapılar, önce tamamen duvarlı olacak şekilde modellenmiş sonra ise, sırayla her katta mevcut olan duvarlar kaldırılarak duvarların olmadığı durumda yapıların periyot ve maksimum deplasman değerlerindeki değişim ile yumuşak kat ve zayıf kat düzensizliği durumlarının oluşumu incelenmiştir. Aynı yapılar 5 katlı olarak da analiz edilmiş ve yapılan tüm analizlerden elde edilen sonuçlara göre, dolgu duvarlı olarak modellenen $\mathrm{N}$ katlı tüm yapı tipleri için yumuşak kat oluşumunun, yapıların 2. ve N-1. katlarında duvarların olmadığı durumlarda meydana geldiği gözlenmiştir.

Anahtar Kelimeler: 2007 Deprem yönetmeliği, Dolgu duvar, Yumuşak kat, Zayıf kat, Deprem düzensizlikleri

\section{Investigation of Soft Story and Weak Story Irregularities on the Structures with Infill Walls}

\begin{abstract}
In this study, soft story and weak story irregularities defined in the Earthquake Code 2007 were investigated. For this purpose, five different 10-story structures with different geometries and infill walls were analyzed using the Equivalent Seismic Load Method in line with both earthquake directions. The infill walls were modeled by the equivalent diagonal compression strut model and the SAP2000 program was used for all the analysis. First of all, structures that were identified by the letter of C, D, E, F and G
\end{abstract}

\footnotetext{
*Sorumlu yazar (Corresponding author): Duygu ERTÜRKMEN, dbasli@cu.edu.tr
} 
were completely modeled with using the infill walls. Then the walls that exist in each story of the structures were removed sequentially. For each situation the changes of the period, the maximum displacement values and the formation of the soft story and weak story irregularities of the structures were investigated. Within the scope of this study, the same structure models which have five stories were also analyzed. Finally, according to the results obtained from the analysis, it was observed that for all the $\mathrm{N}$-Story types of structures modeled with using infill walls, the soft story irregularities have occurred in second and $(\mathrm{N}-1)^{\text {th }}$ stories of the structures due to the absence of the walls in these stories.

Keywords: Earthquake code 2007, Infill wall, Soft story, Weak story, Earthquake irregularities

\section{GİRIŞ}

DBYBHY-2007'de düşey düzensizlikler arasında yer alan ve yapıların büyük oranda hasar görmesine neden olan en önemli etkenlerden biri yumuşak kat düzensizliğidir. Yumuşak kat, matematiksel olarak, birbirine dik iki deprem doğrultusunun herhangi biri için, herhangi bir i'inci kattaki ortalama göreli kat ötelemesinin, bir üst kattaki ortalama göreli kat ötelemesine oranı olarak tanımlanan Rijitlik Düzensizliği Katsayısı $\left(\eta_{\mathrm{ki}}\right)$ 'nin 2,00'den büyük olma durumu şeklinde tanımlanmaktadır.

Ülkemizde birçok konut ve işyeri binası özellikle giriş katlarında yumuşak kat yanlışı yapılarak inşa edilmiştir. $\mathrm{Bu}$ şekilde tasarlanmış binalarda karşılaşılan tipik deprem hasarları, genellikle binanın üst katlarının alt kattaki yumuşak kat üzerine çökmesi şeklinde gerçekleşmektedir. Bu tip bir hasar sonrası binanın kullanılabilmesi mümkün olamayacağından binanın tamamen yıkılarak yeniden inşa edilmesi gerekecektir.

Zemin katı, dükkân ve asma katlı dükkân olan binalarda, zemin kat bölme duvarları genellikle bulunmamaktadır. Üstte konut olarak kullanılan katlar ise bölme duvarlar nedeni ile daha rijit davranmakta ve tüm enerji tüketimi zemin katta yoğunlaştığından, bu tür yapılarda yumuşak kat oluşarak hasar meydana gelmektedir. Yumuşak katın deplasmanı yaklaşık olarak binanın tüm deplasmanına eşittir. Bir kat üzerinde yoğunlaşan bu aşırı deplasman, ötelenme nedeni ile o katın kolonlarını beklenmedik şekilde aşırı hasara uğratabilir ve çoğu zaman binanın göçmesine neden olabilir. Özellikle deprem enerjisinin bu katta karşılanacağı göz önüne alınarak burada yer alan kolon ve perdelerin rijitlikleri, kat arasında oluşacak deplasmanı karşılayabilecek şekilde artırılmalıdır.

Şekil 1'de görülen zemin katları dükkân, üst katları konut olarak kullanılan bu yapida zemin kat, deprem sonrası oluşan yumuşak kat etkisi nedeni ile ötelenerek yıkılmıştır. Yapının yıkılmasında zemin ve asma katta bölme duvarların olmamas1, kat yüksekliğinin fazlalığı ve duvarların olmadığı bu kattaki kolon kesitlerinin yetersizliği gibi sebepler etken olmuştur [1].

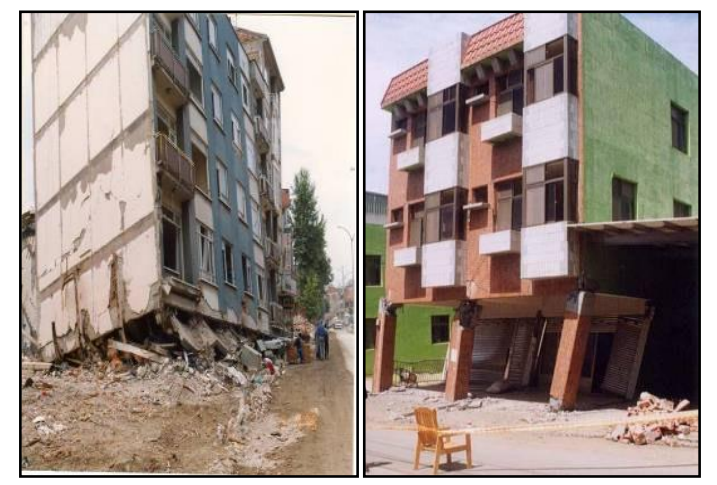

Şekil 1. Yumuşak kat etkisi [1]

Benzer şekilde yığma dolgu duvarları olmayan zemin katın, deprem etkisi altında meydana gelecek yatay deplasmanlara karşı dayanımı, yığma dolgu duvarlarının bulunduğu üst katlara göre oldukça azdır. Bu da katlar arasında rijitlik farklılığını oluşturmaktadır. Düşey yönde rijitlik süreksizliği bulunan bu katlara zayıf kat denilmektedir. Zemin kat yüksekliğinin üst katlara nazaran daha fazla olması da, zayıf kat düzensizliğini yaratan ayrı bir durumdur.

Şekil 2'de gösterilen zemin katı iş yeri olarak kullanılan asma katlı yapıda, zemin kat zayıf kat 
oluşumu nedeniyle bu kat hizasından göçerek yıkılmıştır [2]. Normal katlar ise bölme duvarların varlığı nedeni ile daha rijit davranmaktadır.

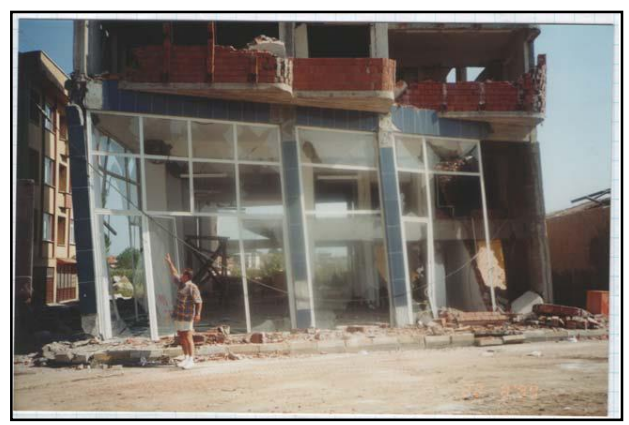

Şekil 2. Zayıf kat hasarı [2]

Mevcut analiz ve tasarım tekniklerinde çerçeve sistemli betonarme binaların sadece kolon, kiriş ve döşemelerinin sistemde taşıyıcı oldukları, dolgu duvarların yatay yükler altında taşıyıcı etkilerinin ihmal edildiği analizler yapılmaktadır. Dolgu duvarların yapı rijitliğine katkısının ihmal edilmesinin nedenleri aşağıda sıralanmaktadır [3].

1. Dolgu duvarların katkısını dikkate alan hesap modelleri oluşturmak nispeten güç ve karmaşık olabilmektedir.

2. Dolgu duvarların katkısını dikkate alan hesap metotları, en azından proje tasarımı seviyesinde yoktur.

3. Yapının enerji yutma kapasitesine ve rijitliğine katkısı genel olarak bilinmesine rağmen güvenli tarafta kalınması için hesaplarda dolgu duvarların etkisi ihmal edilmektedir.

Oysa dolgu duvarlar betonarme yapıların iç bölümlerinde ve dış kısımlarında kullanılmakta ve yapıyı dış ortamdan ayıran, yapıda mimari açıdan farklı mekânların oluşturulmasını sağlayan yapı elemanlarıdır. Ayrıca yapısal olmayan elemanlar olarak düşünülmelerine karşın, deprem yüklerine maruz kaldıklarında çerçeveyle birlikte çalışmaktadırlar.

Bugüne kadar meydana gelen birçok deprem sırasında binalarda oluşan hasarlar üzerinde yapılan gözlem ve araştırmalarda dolgu duvarlarda büyük kalıcı şekil değiştirmelerin oluştuğu saptanmıştır.

Dolgu duvar deprem anında ilk çatlayan eleman olmasına rağmen, depremin ilk anında büyük oranda depreme karşı koymakta ve çatlayarak enerjinin bir kısmını sönümlemektedir. Yapılan araştırmalar dolgu duvarların yapının deprem davranışını büyük ölçüde etkilediğini göstermiştir. Periyod, rijitlik, süneklik ve yük taşıma kapasitesi gibi taşıyıcı sistem davranış özelliklerine önemli derecede etkileri saptanmıştır. Bununla birlikte planda dolgu duvarların düzensiz yerleştirilmesi ve binayı kullananlar tarafindan keyfi olarak kaldırılması burulmaya ve yumuşak kat oluşumuna neden olmaktadir.

Bahsedilen tüm bu sebeplerden dolayı, dolgu duvarların olumlu etkilerinden yararlanmak ve olumsuz etkilerinden korunmak amaciyla dolgu duvarlı çerçevenin modellenerek deprem analizinin yapılması gerekmektedir.

Dolgu duvarların yapı davranışı üzerinde oluşturduğu etkilerin belirlenmesi için bugüne kadar birçok çalışma yapılmıştır. Genel olarak ifade etmek gerekirse; oluşan bu etkiler aşağıda maddeler halinde özetlenmiştir [4].

- Yapının rijitliği artar, doğal periyodu azalır.

- Deprem etkisinden dolayı meydana gelen yanal kuvvetler artar.

- Plan ve kesitteki yük dağılımı değişir.

- Deprem kuvvetlerinin bir k1smı duvarlar yük taşıma kapasitelerine ulaşana kadar duvar tarafından taşınır, yapı taşıyıcı sistemine gelen yük düzeyi azalır.

- Yapının enerji yutma kapasitesi artar.

- Yumuşak kat oluşumuna sebep olabilir.

- Kisa kolon oluşumuna sebep olabilir.

- Planda dolgu duvarların simetrik dağılmaması durumu ise, burulmaya sebep olabilir.

Yapılan bu çalışmada, yapılarda yumuşak kat (rijitlik) ve zayıf kat düzensizliklerinin oluşma nedenlerinin belirlenmesi ve oluşmalarını engelleyecek tasarım ilkelerinin açıklanması amaçlanmıştır. Bu amaçla, C, D, E, F ve G isimleri ile adlandırılan 10 katlı 5 farklı yapı için eşdeğer 
deprem yükü yöntemi kullanılarak deprem hesabı yapılmış; yumuşak kat ve zayıf kat düzensizliklerinin oluşumu ve yapıların davranışı üzerindeki etkileri incelenmiştir.

\section{2. ÖNCEKİ ÇALIŞMALAR}

Gerek k1smen gerekse tamamen dolgu duvarlı olarak tasarlanan betonarme çerçevelerin yatay yükler altındaki davranışlarının belirlenmesi üzerine bugüne kadar çok sayıda teorik ve deneysel araştırma yapılmıştır:

Smith [5], dolgu duvarlı çerçevelerin yatay rijitlik ve dayanımının duvar boyutları ve fiziksel özelliklerinin yanı sıra duvar ile kolon arasındaki temas uzunluğuna bağlı olduğunu göstermiştir.

Mainstone [6], dolgu duvarlı çerçevelerin analizini kolaylaştırmak amacıyla eşdeğer basınç çubuklarını önermiştir. $\mathrm{Bu}$ çubukların genişliklerinin hesabı için de çeşitli formülasyonlar geliştirmiştir.

Livaoğlu ve Doğangün [7], çalışmalarında rijitlik ya da yumuşak kat düzensizliği olarak adlandırılan düzensizliğin oluşmasını engelleyecek olan tasarım ilkelerini açıklamayı amaçlamışlardır. Sonuç olarak, perde çerçeve sistemlerde doğru yerleştirilen perdenin yumuşak kat düzensizliğinin ortaya çıkmasını engellediğini, ayrıca zemin kat yüksekliğinin diğer katların yüksekliğinden fazla olması halinde yumuşak kat davranışının oluşacağını gözlemlemişlerdir.

Sivri [8], dolgu duvarların yapı rijitliğini arttırdığı için yapı periyodu ve yanal yer değiştirmelerin rijitliğe bağlı olarak azaldığı sonucuna varmıştır.

Tetik [9], dolgu duvarların yapının rijitliğini önemli ölçüde arttırdığını, böylece yap1 periyodunda azalmaya neden olduklarını saptamıştır. Dolgu duvarlardaki boşlukların rijitlikte neden olduğu azalmayı incelemiş ve boşluksuz durumunda \%56 mertebelerinde olan periyot azalma oranının \%37’ye düştüğünü hesaplamıştır. İncelenen binalarda, dolgu duvarların, yapı periyotlarında ortalama \%50 $\% 70$ oranında azalmaya neden olduklarını görmüştür.

Tezcan ve arkadaşları [2], yönetmelikte yer alan yetersiz ve yanıltıcı olan kriterlerin düzeltilebilmesi ve zayıf/yumuşak kat düzensizliğinin giderilebilmesi için çeşitli önerilerde bulunmuşlardır.

Beklen [10], dolgu duvarların rijitlik, periyot, yatay deplasman, taban kesme kuvveti gibi değerleri ve bina davranışını önemli ölçüde etkilediğini görmüştür.

\section{MATERYAL ve METOT}

\subsection{Materyal}

Yapılan çalışma kapsamında, farklı geometriye sahip dolgu duvarlı 10 katlı 5 farklı bina modeli üzerinde, $\mathrm{X}$ ve $\mathrm{Y}$ deprem yönlerinde deprem analizleri gerçekleştirilmiştir.

Analizlerde dolgu duvarlar eşdeğer basınç çubuğu şeklinde modellenmiş ve hesap için Eşdeğer Deprem Yükü Yöntemi kullanılmıştır. Önce yapı tamamen dolgu duvarlı olarak modellenmiş; sonra ise birer kat artımlarla ara katlarda duvarlar kaldırılarak duvarların var olmamasının yapı güvenliğini ne şekilde etkilediği araştırılmıştır. Burada amaç; yapıda hangi katta dolgu duvarların modellenmemesi halinde, yumuşak kat düzensizliği değerinin maksimum değere erişeceğinin tespiti ile özellikle zemin katta duvarın modellenmemesi durumunda zayif kat oluşumunun yapıyı ne şekilde etkileyeceğinin belirlenmesidir.

Analizlerde göz önüne alınan yapıların geometrik şekilleri Şekil 3 (a-e)'de şematik olarak verilmektedir: 


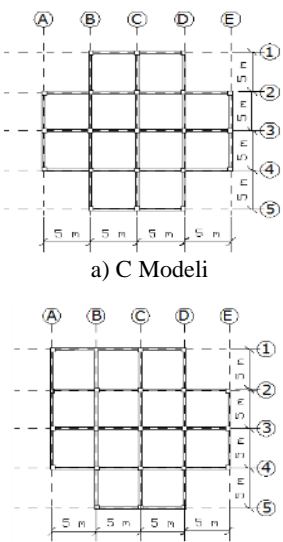

c) E Modeli

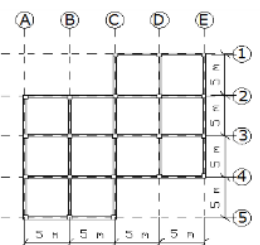

b) D Modeli

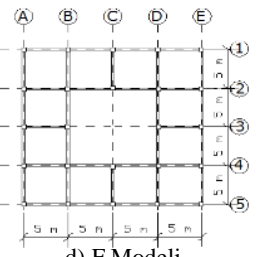

d) F Modeli

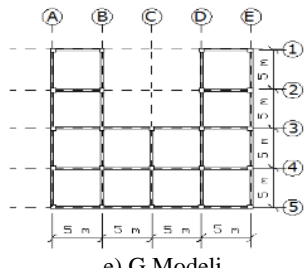

e) G Modeli

Şekil 3 (a-e). Farklı geometrideki yapı modelleri

Tasarım ve modellemede, kesit planları Şekil 3 (a-e)'de verilen yapıların, 1.derece deprem bölgesinde bulundukları varsayılmış ve tüm kat yükseklikleri 3,00 m değerinde alınmıştır. Döșeme kalınlığ $12 \mathrm{~cm}$, kiriş boyutları $(50 \times 30) \mathrm{cm}^{2}$ ve kolon boyutları $(50 \times 50) \mathrm{cm}^{2}$ olarak seçilmiştir. Kullanılan dolgu duvar kalınlıkları ise iç cephe duvarlarında 10 , dış cephe duvarlarında ise $20 \mathrm{~cm}$ değerinde alınarak duvarlara ait genişlikler, Mainstone ve Weeks [11]'in çalışmalarında verilen ifadeler kullanılarak belirlenmiştir. Dolgu duvarlara ait elastisite modülü ise; $2850 \mathrm{MPa}$ değerinde seçilmiştir. Yapılara etkiyen ağırlıkların hesabında kaplama+sıva ağırlığı $100 \mathrm{~kg} / \mathrm{m}^{2}$, tuğla duvar ağırlı̆̆ı $240 \mathrm{~kg} / \mathrm{m}^{2}$, hareketli yük ise $350 \mathrm{~kg} / \mathrm{m}^{2}$ değerinde alınmıştır. Taşıyıcı sistem türü yerinde dökme betonarme çerçeve olup yapılara ait zemin sinıfi Z3 olarak verilmiştir. Hesaplarda kullanılan etkin yer ivmesi katsayısı $\mathrm{A}_{0}=0,4$, taşıyıcı sistem davranış katsayısı $\mathrm{R}=8$ 'dir.

\subsection{Metot}

Şekil 3 (a-e)'de kesit planları verilmiş olan 10 katlı 5 farklı yapı modeli, içte ve dışta tamamen duvarlı olacak şekilde, eşdeğer basınç çubuğu modeli kullanılarak modellemiş ve her iki deprem yönü göz önüne alınarak Eşdeğer Deprem Yükü Yöntemi ile analiz edilmiş̧ir.

$\mathrm{Bu}$ yöntemde taşıyıcı sistemi kolon, kiriş ve perdelerden oluşan yapılara etkiyen deprem yükleri, yapının kat hizaları seviyesinde etkiyen yatay yükler olarak kabul edilir. Bu yatay yüklerin, binanın birbirine dik iki asal doğrultularında ayrı ayrı etkidiği varsayılarak, taşıyıcı sistemi oluşturan elemanlarda kesit tesirleri bulunmaktadır.

Yapılan analizlerde ele alınan yapı modellerinde perde elemanı kullanılmamış, kolon ve kirişlerden oluşan taşıyıcı betonarme çerçeve sistemi, hem içte hem de dişta tamamen dolgu duvarlı olacak şekilde tasarlanmıştır. Sonra modellenen dolgu duvarlar her katta sırasıyla kaldırılarak oluşturulan süreksizliğin, yapıların davranışında meydana getireceği değişiklikler incelenmiştir. Özellikle yapıların periyot ve maksimum deplasman değerlerinde ki değişim ile yapılarda oluşabilecek olan yumuşak kat ve zayıf kat düzensizliği değerleri belirlenmeye çalışılmıştır.

Eşdeğer basınç çubuğu modeli (Şekil 4) ile tanımlanan dolgu duvarların genişliklerinin hesabı için; Mainstone ve Weeks [11]'in önerdiği (1), (2) ve (3) eşitliklerinde verilen formülasyonlardan yararlanılmıştır.

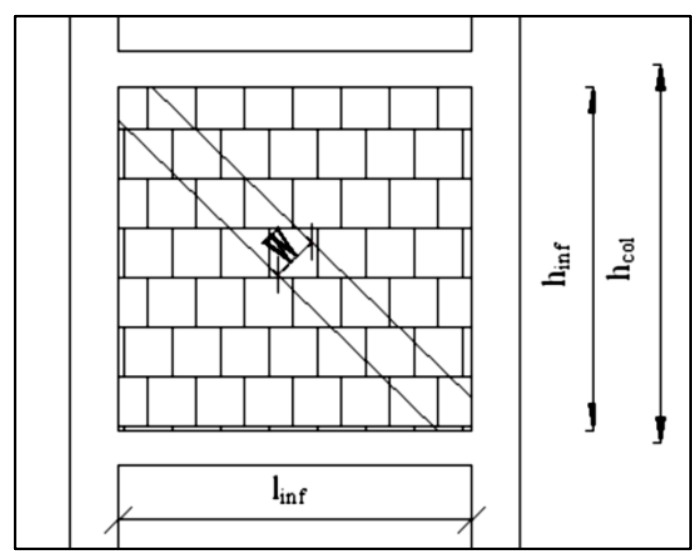

Şekil 4. Eşdeğer sanal basınç çubuğunun oluşumu

$W=0,175\left(\lambda_{1} \cdot h_{c o l}\right)^{-0,4} \cdot L_{i n f}$ 
$\lambda_{1}=\left[\frac{E_{m e} \cdot t_{i n f} \cdot \operatorname{Sin} 2 \varphi}{4 \cdot E_{f e} \cdot I_{c o l} \cdot h_{\text {inf }}}\right]^{1 / 4}$

$\varphi=\operatorname{Tan}^{-1}\left(\frac{h_{\text {inf }}}{L_{\text {inf }}}\right)$

Burada; (W) Sanal basınç çubuğunun genişliği, $\left(\mathrm{h}_{\mathrm{col}}\right)$ kolonun yüksekliği, $\left(\mathrm{L}_{\text {inf })}\right.$ dolgu duvar boyu, $\left(\mathrm{h}_{\text {inf }}\right)$ dolgu duvar yüksekliği, $\left(\mathrm{t}_{\text {inf }}\right)$ dolgu duvar kalınlığı, $\left(\mathrm{E}_{\mathrm{me}}\right)$ dolgu duvarın elastisite modülü, $\left(\mathrm{E}_{\mathrm{fe}}\right)$ kolonun elastisite modülü, $\left(\mathrm{I}_{\mathrm{col}}\right)$ kolonun atalet momenti, $(\varphi)$ sanal basınç çubuğunun yataydaki açısı ve $(\alpha)$ relatif rijitlik katsayısıdır.

Yapılan analizler sonucunda elde edilen sonuçlar yapılarda yumuşak kat ve zayıf kat düzensizliklerinin oluşumu açısından değerlendirilmiştir. Yapıların periyot, maksimum deplasman, yumuşak kat düzensizliği değerlerindeki değişim grafiksel ortamda elde edilmiştir.

2007 Deprem Yönetmeliği'nde bulunan en önemli yap1 düzensizliklerinden biri olan yumuşak kat düzensizliği; birbirine dik iki deprem doğrultusunun herhangi biri için, \%5'lik yatay kuvvet dıș merkezliği altında oluşan, herhangi bir i'inci kattaki ortalama göreli kat ötelemesinin bir üst veya bir alt kattaki ortalama göreli kat ötelemesine oranı olarak tanımlanmaktadır. Ayrıca yönetmelikte $\eta_{k i}$ ifadesi ile tanımlanan Rijitlik Düzensizliği katsayısının, 2.00'den fazla olması durumu, ilgili yapıda yumuşak kat düzensizliğinin varlığını temsil etmekte olup bir yapıda yumuşak kat düzensizliğinin var olup olmadığı (4) ve (5) denklemleri kullanılarak kontrol edilmektedir.

$\eta_{\mathrm{ki}}=\left(\Delta_{\mathrm{i}} / \mathrm{h}_{\mathrm{i}}\right)_{\text {ort }} /\left(\Delta_{\mathrm{i}+1} / \mathrm{h}_{\mathrm{i}+1}\right)_{\mathrm{ort}}>2.0$

$\eta_{\mathrm{ki}}=\left(\Delta_{\mathrm{i}} / \mathrm{h}_{\mathrm{i}}\right)_{\text {ort }} /\left(\Delta_{\mathrm{i}-1} / \mathrm{h}_{\mathrm{i}-1}\right)_{\text {ort }}>2.0$

Komşu katlar arası dayanım düzensizliği olarak da bilinen zayıf kat düzensizliği durumu ise; betonarme binalarda, birbirine dik iki deprem doğrultusunun herhangi birinde, herhangi bir kattaki etkili kesme alanının (kolon + perde $+0,15$ $\times$ kagir duvar alanı), bir üst kattaki etkili kesme alanına oranı olan, $\eta_{\mathrm{ci}}$ Dayanım Düzensizliği katsayısının, 0.80’den küçük olması halidir. $\eta_{\mathrm{ci}}=\left(\sum \mathrm{A}_{\mathrm{e}}\right)_{\mathrm{i}} /\left(\sum \mathrm{A}_{\mathrm{e}}\right)_{\mathrm{i}+1}<0.80$

Herhangi bir kattaki etkili kesme alanının ifadesi;

$\sum \mathrm{A}_{\mathrm{e}}=\sum \mathrm{A}_{\mathrm{w}}+\sum \mathrm{A}_{\mathrm{g}}+0.15 \sum \mathrm{A}_{\mathrm{k}}$

olarak hesaplanmaktadır.

Bu bağıntılarda;

$\sum \mathrm{A}_{\mathrm{w}}$ : Herhangi bir kattaki kolon en kesiti etkin gövde alanları toplamını,

$\sum \mathrm{A}_{\mathrm{g}}$ : Binada herhangi bir katta, hesap yapılan deprem doğrultusuna paralel doğrultuda perde olarak (planda boyu eninin 7 katından büyük eleman) çalışan taşıyıcı sistem elemanlarının en kesit alanlarının toplamını,

$\sum \mathrm{A}_{\mathrm{k}}$ : Binada herhangi bir katta, kapı ve pencere boşlukları çıkartıldıktan sonra, hesap yapılan deprem doğrultusuna paralel kagir dolgu duvar alanlarının toplamını göstermektedir.

\section{ARAŞTIRMA BULGULARI}

Farklı geometriye sahip C, D, E, F ve G modeli olarak isimlendirilen 10 katlı 5 farklı yap1 modeli için dolgu duvarların modellenmediği, boş kat olarak alınan katın değişimine bağlı olarak, elde edilen yumuşak kat düzensizliği değerleri ile periyot ve deplasman değerleri değişimleri Şekil 5 (a-b), Şekil 6 (a-b) ve Şekil 7 (a-b)'de verilen grafiklerde yer almaktadır.

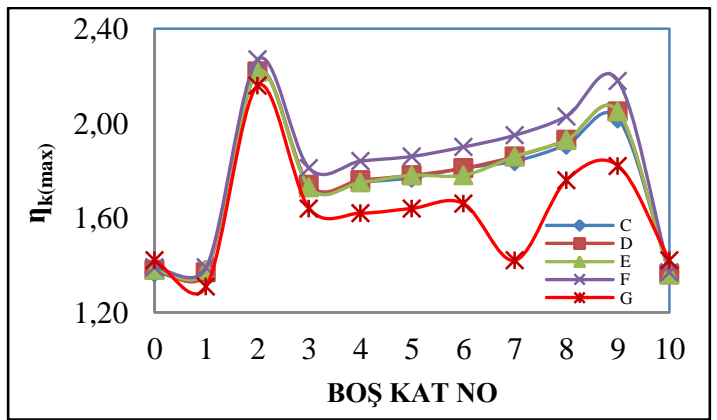

Şekil 5 (a). X yönü maksimum yumuşak kat düzensizliği değerleri değişimi 
Şekil 5 (a)'da görüldüğü gibi, X deprem yönünde yapılan analizler sonucunda elde edilen maksimum yumuşak kat düzensizliği değerleri, $G$ modeli hariç diğer tüm modeller için 2. ve 9. katlarda duvarların modellenmediği durumlarda sınır değer olan 2,00 değerini aşmaktadır. G modeli için ise, sadece 2. katta duvar yokken yumuşak kat oluşumu gözlenmiştir. Yumuşak kat sorununu simgeleyen maksimum değerler ise F modeli için oluşmuş olup 2,27 değerine kadar ulaşmıştır.

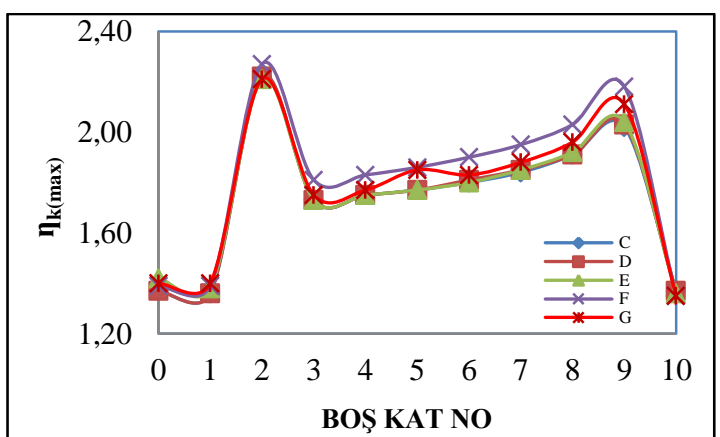

Şekil 5 (b). Y yönü maksimum yumuşak kat düzensizliği değerleri değişimi

Şekil 5 (b)'de verilen grafikte de görüldüğü gibi, Y yönünde yapılan analizler sonucunda elde edilen maksimum yumuşak kat düzensizliği değerleri, tüm modeller için yine 2. ve 9. katlarda duvarların modellenmediği durumlarda sinır değer olan 2,00 değerini aşmaktadır. Maksimum değerler yine $\mathrm{F}$ modeli için oluşmuş olup 2,27 değerine kadar ulaşmıştır.

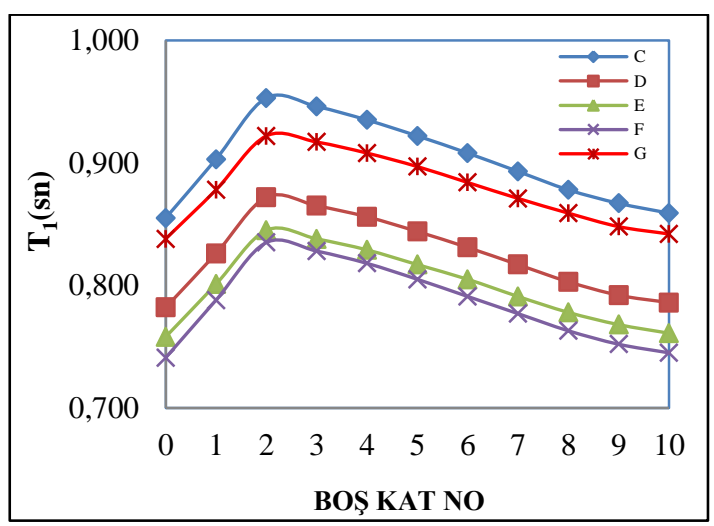

Şekil 6 (a). Farklı geometrideki modeller için X yönündeki periyot değerleri değişimi

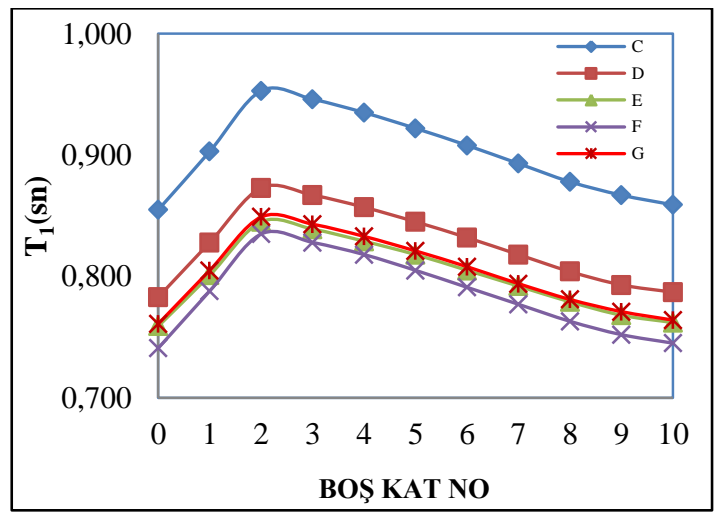

Şekil 6 (b). Farklı geometrideki modeller için Y yönündeki periyot değerleri değişimi

Şekil 6 (a-b)'de verilen grafiklerde görüldüğü gibi, her iki deprem yönünde yapılan analizler sonucunda elde edilen periyot değerleri, tüm modeller için 2. katta duvarlar modellenmediğinde oluşmaktadır. Bunun nedeni, ilgili katta duvarlar var olmadığında, yapının rijitliğinin bu katta diğer katlara oranla daha fazla azalmış olmasıdır.

Şekil 7 (a-b)'de verilen grafiklerde görüldüğü gibi, her iki deprem yönünde yapılan analizler sonucunda elde edilen maksimum deplasman değerleri, tüm modeller için 2. katta duvarlar modellenmediğinde oluşmaktadır. Bunun nedeni, yine bu katta duvarların var olmamasindan kaynaklanan dayanım azalması ve dolayısıyla yapının bu katta diğer katlara oranla daha fazla deplasman yapmış olmasıdır.

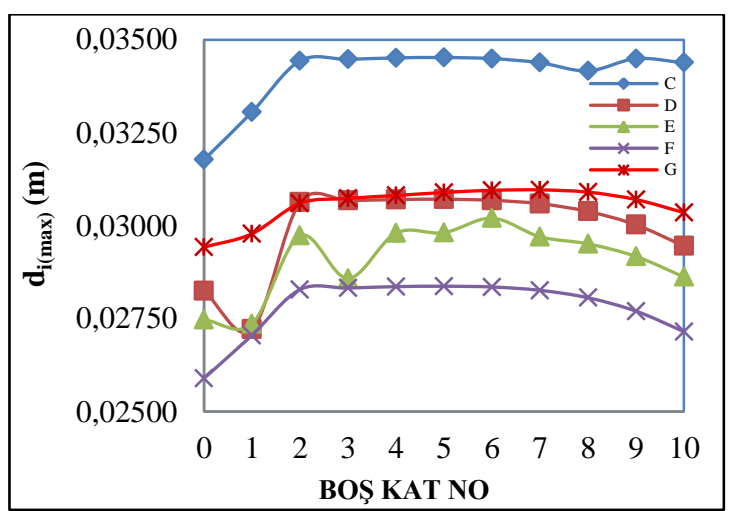

Şekil 7 (a). Farklı geometrideki modeller için X yönündeki maksimum deplasman değerleri değişimi 


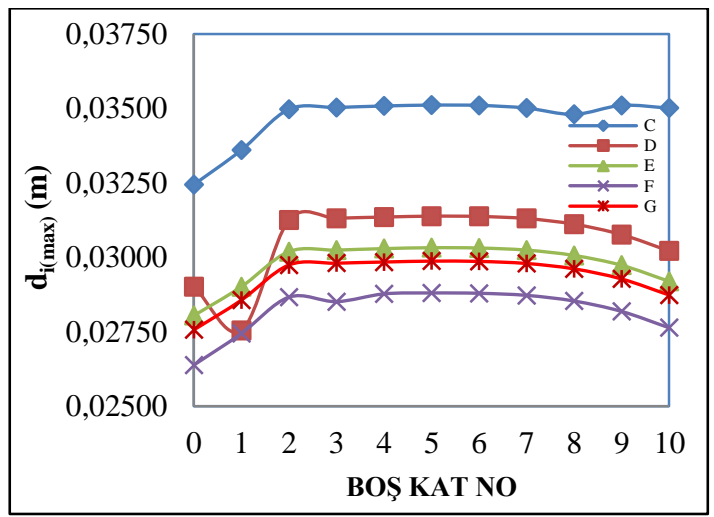

Şekil 7 (b). Farklı geometrideki modeller için Y yönündeki maksimum deplasman değerleri değişimi

Yapılan analiz sonuçlarına göre zayıf kat düzensizliğinin, incelenen tüm yapı modelleri için dolgu duvarların modellenmediği katlarda ortaya çıktığı saptanmıştır. Değerleri ise ilgili kat için hesaplanan etkili kesme alanı ile ilgili kata göre bir üst kat için hesaplanan etkili kesme alanının oranı alınarak belirlenmiştir. Hesaplanan bu değerler, seçtiğimiz 10 katlı 5 farklı yapı modeli için yapının 1. katından 9. katına kadar aynı değeri almaktadır. Çünkü tüm katlarda ki kolonların sayısı ve kullanılan dolgu duvar miktarları aynıdır. Sadece 10. katta duvarların modellenmediği durumda zayıf kat oluşmamaktadır.

Göz önüne alınan tüm yapı modelleri için her iki deprem yönünde elde edilen zayıf kat düzensizliği değerleri ise Çizelge 1'de verilmektedir.

Çizelge 1. Tüm yapı modelleri için elde edilen zayıf kat düzensizliği değerleri

\begin{tabular}{ccc}
\hline Yapı Modeli & $\eta_{\mathrm{ci}}(\mathbf{X})$ & $\eta_{\mathrm{ci}}(\mathbf{Y})$ \\
\hline $\mathrm{C}$ & 0,798 & 0,767 \\
$\mathrm{D}$ & 0,798 & 0,767 \\
$\mathrm{E}$ & 0,768 & 0,768 \\
$\mathrm{~F}$ & 0,750 & 0,776 \\
$\mathrm{G}$ & 0,783 & 0,742 \\
\hline
\end{tabular}

\section{TARTIŞMA VE SONUÇLAR}

Günümüzde mevcut bulunan betonarme binaların çoğunluğunda zemin katlarda mağaza, restoran ve banka gibi ticari mekânların yer almasını sağlamak ve bu kısımlarda daha geniş alanlar oluşturmak amaciyla üst katlarda fazlaca bulunan dolgu duvarlar yapıların bu bölümlerinde kaldırılmaktadır. Bina, sağlam gibi görünse de bu katlarda yapiya gelen yatay kuvvetler üst katlardaki kadar rijit bir şekilde karşılanamamakta ve önlem alınmaması halinde, herhangi bir deprem etkisinde bu tarz yapılar meydana gelen yumuşak kat ve/veya zayıf kat durumundan dolayı ağır derecede hasarlanarak yıkılmaktadır.

Deprem etkisi altında binalarda oluşabilecek bu olumsuzlukların nedenlerini daha iyi kavramak; yumuşak kat ve zayıf kat varlığının yapı davranışı üzerindeki etkisini araştırmak amacıyla yapılan bu çalışmadan elde edilen sonuçlara ait yorumlar genel olarak aşağıda verilmektedir.

- Yumuşak kat düzensizliği değerleri, tüm modeller için 10 katlı yapıda 2. ve 9. katlarda duvarlar modellenmediğinde sınır değer olan 2.00 değerini aşmaktadır. Kontrol amaçlı olarak aynı yapı modelleri 5 katlı olarak da analiz edilmiş ve 5 katlı yapıda da 2. ve 4. katlarda dolgu duvarların olmadığı durumda yumuşak kat düzensizliğinin oluştuğu saptanmıştır. Buna göre genel bir yorumla; $\mathrm{N}$ katlı herhangi bir yapıda yumuşak kat düzensizliği oluşum riskinin yapının 2. ve N-1. katlarında dolgu duvarların var olmaması nedeni ile ortaya çıkabileceği söylenebilmektedir.

- Yap1 modellerine ait hesaplanan maksimum serbest titreşim periyodu değerleri, 10 katlı yapıda 2. katta dolgu duvar bulunmadığı durumda oluşmaktadır. Bunun nedenini açıklamak gerekirse; yapıda bu katta dolgu duvar olmadığında, bir alt veya bir üst katlar arasında oluşan deplasman değerlerinde büyük farklılıklar oluşmaktadır. Dolayısıyla; yapının rijitliği düşmekte ve yapı daha fazla deplasman yapmaktadır. $\mathrm{Bu}$ durum da, yapının periyot değerini arttırmaktadır. Periyot değerinin artması ise rijitliğin azalması anlamına geldiğinden, yapıya yanal kuvvetlerin etkimesine sebep olan deprem 
gibi etkilerin var olması durumunda, dolgu duvarların hesaplarda mutlaka dikkate alınması gerektiği sonucuna varılmıştır.

- Zayıf kat davranışı, birçok yapıda olduğu gibi yapılan analizlerde çalışma kapsamında göz önüne alınan tüm modellerimizde de içinde bulunulan katta duvarların olmayıp bir üst katta veya bir alt katta var olması nedeniyle ortaya çıkan ani rijitlik değişiminden kaynaklanmaktadır. Seçtiğimiz modellerde her katta bulunan kolon ve duvarların sayısı aynı olduğundan hesaplanan etkili kesme alanları da her kat için aynı değerdedir. Bu nedenle elde edilen zayıf kat (dayanım) düzensizliği değerleri de her kat için aynı oranda çıkmıştır. Sadece en üst katta dolgu duvarların olmaması, yapının dayanımı için herhangi bir sorun yaratmamaktadır.

- Bugüne kadar yaşanan depremlerde de görüldüğü gibi gerek yumuşak kat gerekse zayıf kat yanlışlığı yapılarak inşa edilmiş olan binalarda yıkıcı etkiler meydana gelmekte ve maalesef can kayıpları yaşanmaktadır. Mevcutta bulunan binalarda bu yanlışlığın yapılıp yapılmadığı ise, ancak detaylı yapısal bilgiler ve analizler sonrasında kesinlik kazanabilmektedir. Bu sebeple yapılarda herhangi bir nedenle duvarların kullanılmadığı katlarda, mutlaka dayanımı arttırıcı bir takım önlemler alınmalı; ya bu katlardaki kolon boyutları arttırılmalı ya da oluşabilecek yatay deplasmanları karşılayacak ilave perde elemanlar kullanılmalıdır.

\section{KAYNAKLAR}

1. Topçu, A., 2007. Taşıyıcı Sistem Seçiminde Istenmeyen Düzensizlikler: Doğrular, Yanlışlar, Hasarlar, İMO Eskişehir Şubesi, Meslek Içi Eğitim Kursu, Eskişehir.

2. Tezcan, S., Yazıcı, A., Özdemir, Z., Erkal, A., 2007. Zayıf Kat-Yumuşak Kat Düzensizliği, Altıncı Ulusal Deprem Mühendisliği Konferans1, 16-20 Ekim 2007, İstanbul.

3. Sayın, B., 2003. Mevcut Betonarme Yapıların Yeni Deprem Yönetmeliğine Göre Projelendirilmesi ve Güçlendirilmesi Teknikleri, Yüksek Lisans Tezi, İstanbul Üniversitesi Fen Bilimleri Enstitüsü.
4. Dowrick, D.J., 1987. Earthquake Resistant Design for Engineers and Architects, John Wiley \& Sons, New York.

5. Smith, B.S., 1962. Lateral Stiffness of Infilled Frames, ASCE Structural Division Journal, pp. 183- 199.

6. Mainstone, R.J., 1974. Supplementary Note on the Stiffness and Strengths of Infilled Frames, Building Research Station, UK, Current Paper 13/74.

7. Livaoğlu R.,ve Doğangün A., 2003. Burulma Düzensizliği Olan Çok Katlı Yapılarda Rijit ve Esnek Taraflarda Bulunan Elemanların Davranışlarının İrdelenmesi, Beşinci Ulusal Deprem Mühendisliği Konferansı, İstanbul.

8. Sivri, M., 2003. Dolgulu Çerçevelerin Deprem Davranışı, Yüksek Lisans Tezi, Süleyman Demirel Üniversitesi, Fen Bilimleri Enstitüsü, Isparta.

9. Tetik, D., 2007. Dolgu Duvarların Betonarme Yapıların Serbest Titreşimine Etkisi, Yüksek Lisans Tezi, Yıldız Teknik Üniversitesi, Fen Bilimleri Enstitüsü.

10. Beklen, C., 2009. Binalarda Dolgu Duvar Etkisinin İncelenmesi, Yüksek Lisans Tezi, Cukurova Üniversitesi, Fen Bilimleri Enstitüsü.

11. Mainstone R.J., Weeks G.A., 1970. The Influence of Bounding Frame on the Racking Stiffness and Strength of Brick Walls, $2^{\text {nd }}$ International Brick Masonry Conference, Watford, England, 12-15 April, 165-171. 
